this regard, and his renderings of the Arab and Persian poets into verse make delightful reading. The general discriminating public has much to thank him for: the debt of the specialists is no less great. His judgment was as sound as his scholarship, his learning as profound as his application.

As a teacher Nicholson was admirable: to beginners he was understanding and sympathetic, to advanced students he was inspiring and ungrudging in his aid. The rare public lectures he gave were always thronged, and he gave his audiences much to delight them. His shy and retiring manner concealed many great qualities which only a few were privileged to know: they will bear witness to his deep spirituality, his true goodness, and his loyal friendship.

A. J. Arberry.

\title{
Dr. Nicolaas Johannes Krom
}

Nicolaas Johannes Krom was born at 'sHertogenbosch on 5th September, 1883. He studied classics at the University of Leiden, taking Sanskrit and comparative philology, and qualified for his doctor's degree in 1908. Selected to succeed Dr. Brandes as Director of Archæology in Netherlands India, he took up the difficult study of Old Javanese. The years 1910-15 Krom spent in Java, where he made himself familiar with the numerous Hindu remains, his primary duty being the organization of a permanent Archæological Survey. In 1919 he was appointed at Leiden to the newly founded chair for the archæology and ancient history of Netherlands India. His lectures were attended by students reading for the Civil Service, and particularly by future members of the Archæological and Linguistic Surveys.

Krom's fame as the great authority on the antiquities of Indonesia is mainly due to three works of outstanding merit. Best known is his magnum opus on the Barabudur, grand monument of the Mahāyāna. The iconological description of this gigantic stüpa with: ts 1,500 large sculptured panels appeared in 1920. A somewhat abbreviated English version followed in 1927. Krom not only summarized all that had been written on the subject, but added much that was new, e.g. an interpretation of the series of reliefs illustrating the Gandavyüha. 
In his Inleiding tot de Hindoe-Javaansche Kunst (1920, 2nd ed. 1923) Krom deals with all the Brahmanical and Buddhist sanctuaries in Java. It was his object to give only an introduction to IndoJavanese art. The treatment is therefore sober and he abstains from æsthetic digressions.

In his third great work, Hindoe-Javaansche Geschiedenis (1926), Krom shows himself an eminent historian. It is a history of Indonesia and in particular of Java from the beginning of the Hindu colonization till the final triumph of Islām $(c .1525)$. The second edition of 1931 is rewritten to such an extent that it is practically a new work. Dr. C. O. Blagden, when reviewing the book (JRAS., 1928, p. 912), expressed the wish that it might appear in English, and the Greater India Society has an authorized translation in the press.

Krom produced several minor works and numerous articles dealing with every aspect of Indo-Javanese archæology. All his works exhibit sound judgment and a masterly familiarity with every detail in the field of his studies.

J. PH. VoGet.

\section{Otto Stein, 1893-1942}

Otto Stein was born at Saaz in Bohemia in 1893. He was a pupil of Heinrich Swoboda and Moriz Winternitz at the German University in Prague, where he obtained his doctor's degree, was admitted Privatdozent in 1922, and in 1930 succeeded Winternitz in the Chair of Indology. At the end of 1938, being a Jew, he was deprived of his Professorship. Information has now been received from a relative in Prague - the sole survivor of a family of twenty-two persons, himself recently rescued from a concentration camp and from death by the downfall of the Nazis-that in October, 1941, Stein was deported with his wife to Lodz and that they both met their death in April, 1942. It had seemed possible that his amiable personality and honourable record might have saved him ; but such a hope failed to take into account the impersonal ruthlessness of ideological persecution.

Stein was only 48 years of age when his life was cut short, and his active life ended four years before his tragic death. His career 